\title{
Effect of new plastics and leucocyte contamination on in vitro storage of platelet concentrates
}

\author{
MA TAYLOR, NP TANDY, ID FRASER \\ From the South Western Regional Blood Transfusion Centre, Southmead Road, Bristol BS10 5ND.
}

SUMMARY Platelet concentrates were prepared for in vitro storage in either Fenwal PL-732 or Cutter CLX ${ }^{\mathrm{TM}}$ platelet packs. The units were stored at $22^{\circ} \mathrm{C}$ for seven days with either horizontal or tumbler agitation. Measurement of $\mathrm{pH}$, hypotonic shock response and serotonin uptake indicated in vitro viability was well maintained during 5-7 days storage using either type of pack with either mode of agitation. The longer storage interval did not effect either plasma fibrinogen concentrations or binding of monoclonal antibody, AN51. However, gross contamination of the units with leucocytes caused increased glucose consumption, substantial fall in $\mathrm{pH}$ and loss of in vitro viability after five days storage. The work suggests the shelf-life of platelet concentrates can be extended to five days and that they are clinically effective providing the leucocyte contamination is minimised.

The maximum shelf-life of platelet concentrates stored at $22^{\circ} \mathrm{C}$ is at present $72 \mathrm{~h}$ which, with the ever-increasing requirement for platelet concentrates, makes inventory control very difficult. ${ }^{1}$ Previous studies have shown that it is essential to maintain physiological $\mathrm{pH}$ during in vitro storage of platelet concentrates. ${ }^{23} \mathrm{New}$ formulation plastics are being developed which have superior permeability to oxygen and carbon dioxide relative to the currently available packs with the resultant better maintenance of $\mathrm{pH}$. If successful the shelf-life of platelet concentrates may be increased. In the present study two new packs, the Fenwal PL732 (blow-moulded polyolefin containing no plasticiser) and the Cutter CLX ${ }^{\mathrm{TM}}$ (CLX; modified polyvinylchloride) were evaluated using suitable in vitro tests.

Hypotonic shock response (HSR) and serotonin uptake are useful assays for evaluating preserved platelets. ${ }^{4-6}$ Leucocyte contamination, in repeated platelet transfusions, is thought to be the main inducer of recipients becoming immunologically refractory to platelets from random donors.? Although every effort is made during platelet concentrate preparation to minimise the number of contaminating blood cells the preparations may contain variable amounts of erythrocytes and leucocytes. ${ }^{8}$ With extended storage of platelet concentrates being envisaged, constant mechanical mixing may

Accepted for publication 27 July 1983 also increase the degradation of more fragile leucos $\vec{\varphi}$ cytes, with accumulated aggregated protein an\& release of proteolytic enzymes. These enzymes, eve though heat labile, may have adverse effects on the platelets, cleave fibrinogen' and degrade other plasma proteins.

\section{Material and methods}

PREPARATION OF PLATELET CONCENTRATES Fresh whole blood $(450 \mathrm{ml})$ was collected from normal blood donors of group $O$ or $A$ in $63 \mathrm{ml}$ CPD $A_{1}$, anticoagulant (Fenwal R1369 Travenol Labs Ltd, Thetford, Norfolk). Platelet-rich plasma was prepared by centrifugation of whole blood in a Beckman J6-B centrifuge (Beckman RIIC Ltd, Glenrothes, Scotland) with JS4: 2 rotor at $2800 \mathrm{rpm}$ $(2225 \mathrm{~g})$ for $3 \mathrm{~min}$ (total start/stop time $7.5 \mathrm{~min}$ ) at 윽 $22^{\circ} \mathrm{C}$. Two units of group $A$ or $O$ and Rhesus (Rh) compatible platelet rich plasma were pooled in an 800y Transfer Pack (Fenwal R2053). After gentle $N$ mixing the pooled platelet rich plasma was equally distributed, aseptically in a Fenwal PL-732 and Cutter CLX ${ }^{\mathrm{TM}}$ (CLX) platelet pack. The units were cen- $\mathrm{W}$ trifuged at $3200 \mathrm{rpm}(3000 \mathrm{~g})$ for $7 \mathrm{~min}$ (total start/ stop time was $10 \mathrm{~min}$ ). The platelet poor plasma was $\varrho$


the platelet button. The platelet button was left $\stackrel{\oplus}{+}$ undisturbed at room temperature for $1 \frac{1 / 2}{2}-\mathrm{h}^{10} 7$ before resuspension. The platelet poor plasma was stored in $20 \mathrm{ml}$ aliquots at $-30^{\circ} \mathrm{C}$ for use in subse- 
quent assays. Platelet concentrates were stored in an incubator (Coombes Platelet Incubator, Coolcrest Engineering Ltd, Bristol) at $22 \pm 2^{\circ} \mathrm{C}$ for the storage period with continuous gentle agitation either tumbler rotation 6 cycles/min (Helmer Lab marketed by Horwell Ltd, London) or horizontally by laying the bags unstacked on open wire racks mounted on a platform rotator (Luckhams Ltd, Burgess Hill, West Sussex) adjusted to 70 cycles $/ \mathrm{min}$.

\section{BUFFY COAT PREPARATION}

Buffy coat was removed from the donation of whole blood, immediately after the platelet rich plasma had been expressed. Two units of $A, O$ and $R h$ compatible buffy coat were pooled together in a $150 \mathrm{ml}$ Transfer Pack (Fenwal 4R 2001), selecting the same units as would be pooled for comparative platelet assessment. One volume 6\% Dextran 150 saline (Fisons Ltd, Pharmaceutical Division) was added to 10 volumes of the buffy coat pool. The unit was allowed to sediment for one hour in a plasma expressor, after which time the leucocyte rich supernatant was removed with a $25 \mathrm{ml}$ syringe and needle $16 \mathrm{G}$ via a medical injection site coupler (Fenwal $4 C 2405$ ). This supernatant was added to one of the paired units of platelet rich plasma, the other unit of platelet rich plasma being given an equivalent amount of $6 \%$ Dextran only. Both units of platelet rich plasma were then processed as above. The final estimated concentration of Dextran 150 saline in the platelet concentrate was approximately $0 \cdot 2 \%$.

\section{SAMPLING}

Five $\mathrm{ml}$ samples of each platelet concentrate were removed aseptically using a sampling site coupler (Fenwal 4C 2405) under Laminar air flow at 0, 3, 5 and 7 days of storage.

\section{IN VITRO ASSAYS}

Determination of platelet and white blood cell counts and mean platelet volume (MPV) were carried out using a Coulter S plus (Coulter Electronics Ltd, Luton, Beds).

The $\mathrm{pH}$, hypotonic shock response, serotonin uptake and adenosine-5-diphosphate (ADP)induced aggregation studies were carried out as previously described ${ }^{5}$ with certain modifications to the HSR assay. Platelet concentrate was diluted 1 volume to 3 volumes platelet poor plasma prior to testing. The hypotonic shock response was subsequently measured at $2 \mathrm{~min}$ and $5 \mathrm{~min}$ intervals.

Glucose estimations were carried out on a Beckman glucose Analyser 2 (Beckman RIIC Ltd), while the fibrinogen estimates were determined by Clot Weight Technique using the method of Ingrams ${ }^{11}$ as modified by Royal Free Hospital Haemophilia
Centre.

Formaldehyde-treated platelets were prepared by a modification of the method described by Macfarlane et al.$^{12}$ Platelet preparations were washed three times in $0.01 \mathrm{M}$ Tris, $0.01 \mathrm{M}$ EDTA, $0.15 \mathrm{M} \mathrm{NaCl}$ $\mathrm{pH} 7.5$ (TES) by repeated centrifugation in an IEC Centra 7 centrifuge at $1500 \mathrm{~g}$ for $8 \mathrm{~min}$. The platelets were then resuspended in TES pH 7.5 containing $1 \%$ formaldehyde. After incubation for at least $18 \mathrm{~h}$ at $4^{\circ} \mathrm{C}$ the platelets were washed three times with TES and resuspended in this buffer prior to storage at $4^{\circ} \mathrm{C}$. The binding of monoclonal antibody AN $51^{13}$ was assayed using a double antibody assay. ${ }^{14}{ }^{125}$ I-labelled sheep or rabbit anti-mouse $F$ (ab) ${ }_{2}$ fragment (Amersham International Ltd) was diluted with unlabelled affinity purified rabbit anti-mouse IgG (prepared as described by Jensenius and Williams, ${ }^{14} 1.56 \mu \mathrm{Ci} / \mathrm{ml} ; 98.4 \mu \mathrm{g}$ protein $\left./ \mathrm{ml}\right)$ and $6.9 \mu \mathrm{g}$ protein was added to each test.

\section{STATISTICS}

Statistical analysis was carried out using Student's $t$ test.

\section{Results}

The initial platelet counts of paired platelet concentrates prepared for storage in either the Cutter CLX or Travenol PL-732 platelet packs were $1400 \pm 460 \times 10^{9} / 1 \quad(n=11 ;$ Cutter CLX $)$ and $1270 \pm 350 \times 10^{9} / 1(n=11 ;$ Travenol PL 732) and the count remained unchanged with storage up to seven days. These platelet concentrates were stored with either tumbler $(n=12)$ or horizontal $(n=10)$ mixing and comparison of these two methods of mixing for each type of platelet pack showed very similar results with storage for seven days. Thus the $\mathrm{pH}$, hypotonic shock response and serotonin uptake are presented irrespective of the method of mixing (Table 1). An initial increase in $\mathrm{pH}$ was observed in some units stored in both types of packs at three days storage and the $\mathrm{pH}$ had declined by five days storage. The $\mathrm{pH}$ of the platelet concentrates was well maintained over seven days storage with a minimum pH of 6.5 observed when platelet concentrates were stored in Travenol packs whereas one of the units had a $\mathrm{pH}$ of 5.6 with storage in Cutter packs. There was no significant difference $(\mathrm{p}>0.05)$ in the $\mathrm{pH}$ during storage in either type of pack.

Aggregation induced by ADP $(100 \mu \mathrm{M})$ was carried out on a limited number of units. The level of aggregation declined with storage and some units gave no response after seven days storage.

Hypotonic shock response was very well maintained over seven days storage with no significant 
Table 1 Comparison of in vitro platelet storage using Cutter and Travenol storage bags

\begin{tabular}{|c|c|c|c|c|c|c|c|c|}
\hline \multirow[t]{2}{*}{ Parameter } & \multicolumn{4}{|c|}{$\begin{array}{l}\text { Cutter } C L X \\
\text { Storage interval }[\text { Mean } \pm S D(\text { days })]\end{array}$} & \multicolumn{4}{|c|}{$\begin{array}{l}\text { Travenol PL-732 } \\
\text { Storage interval }[\text { Mean } \pm S D(\text { days })]\end{array}$} \\
\hline & 0 & 3 & 5 & 7 & 0 & 3 & 5 & 7 \\
\hline $\mathrm{pH}$ & $7 \cdot 3 \pm 0.05$ & $7 \cdot 15 \pm 0 \cdot 5$ & $7 \cdot 1 \pm 0 \cdot 5$ & $6 \cdot 8 \pm 0 \cdot 5$ & $7.35 \pm 0.05$ & $7 \cdot 4 \pm 0 \cdot 15$ & $7 \cdot 3 \pm 0 \cdot 15$ & $7 \pm 0 \cdot 2$ \\
\hline $\begin{array}{l}\text { Hypotonic shock } \\
\text { response } \\
\text { (\% at } 2 \mathrm{~min})\end{array}$ & $59 \pm 12$ & $61 \pm 22$ & $63 \cdot 5 \pm 22$ & $59 \pm 22$ & $61 \cdot 5 \pm 9$ & $67 \pm 8$ & $60 \pm 8$ & $44 \cdot 5 \pm 13 \cdot 4$ \\
\hline $\begin{array}{l}\text { Serotonin uptake } \\
\left(\%{ }^{14} \mathrm{C}-5 \mathrm{HT}\right. \\
\text { remaining after } \\
20 \mathrm{~min})\end{array}$ & $24 \pm 2$ & ND & ND & $53 \pm 21$ & $28 \pm 9$ & ND & ND & $64: \pm 12$ \\
\hline
\end{tabular}

ND $=$ no data.

$\mathrm{n}=11$ for each type of bag.

Table 2 Comparison of in vitro platelet storage in presence and absence of buffy coat

\begin{tabular}{|c|c|c|c|c|c|c|c|}
\hline $\begin{array}{l}\text { Interval } \\
\text { (days) }\end{array}$ & $\begin{array}{l}\text { Hypotonic shock } \\
\text { response } \\
\text { (\% at } 2 \text { min) }\end{array}$ & $\begin{array}{l}\text { Serotonin uptake } \\
\left(\%{ }^{14} \mathrm{C}-5 \mathrm{HT} \text { remaining }\right. \\
\text { after } 20 \mathrm{~min})\end{array}$ & $W B C\left(10^{\circ} / l\right)$ & $p H$ & Glucose ( $\mathrm{mmol} / \mathrm{l})$ & $\begin{array}{l}\text { Platelet } \\
\text { Count }\left(10^{9} / l\right)\end{array}$ & $M P V(f l)$ \\
\hline $\begin{array}{l}\text { With leucc } \\
0 \\
3 \\
5 \\
7\end{array}$ & $\begin{aligned} \text { tes } & \\
38 \cdot 5 & \pm 15 \\
35 & \pm 18 \\
20 & \pm 20 \\
3 \cdot 5 & \pm 7\end{aligned}$ & $\begin{array}{l}49 \pm 13 \\
N D \\
N D \\
99 \pm 3\end{array}$ & $\begin{array}{r}30.2 \pm 8 \\
19.0 \pm 9 \\
13.2 \pm 9 \\
9.5 \pm 6\end{array}$ & $\begin{array}{l}7 \cdot 3 \pm 0.1 \\
6 \cdot 8 \pm 0.5 \\
6 \cdot 3 \pm 0.6 \\
6.0 \pm 0.4\end{array}$ & $\begin{array}{r}26 \cdot 2 \pm 3 \\
15 \cdot 4 \pm 4 \\
10 \cdot 3 \pm 6 \\
7 \cdot 0 \pm 5\end{array}$ & $\begin{array}{l}1442 \pm 172 \\
1338 \pm 195 \\
1371 \pm 163 \\
1409 \pm 150\end{array}$ & $\begin{array}{l}7.4 \pm 0.9 \\
7 \cdot 8 \pm 1 \cdot 2 \\
8 \cdot 3 \pm 1 \cdot 2 \\
8.9 \pm 1.6\end{array}$ \\
\hline $\begin{array}{l}\text { Without le } \\
0 \\
3 \\
5 \\
7\end{array}$ & $\begin{array}{l}\text { cocytes } \\
47 \pm 11 \\
58 \pm 17 \\
52.5 \pm 20 \\
37.5 \pm 25\end{array}$ & $\begin{array}{l}52 \pm 12 \\
\text { ND } \\
\text { ND } \\
61 \pm 24\end{array}$ & $\begin{array}{l}0.9 \pm 0.4 \\
0.9 \pm 0.6 \\
0.9 \pm 0.5 \\
0.8 \pm 0.6\end{array}$ & $\begin{array}{l}7.3 \pm 0.1 \\
7 \cdot 3 \pm 0.2 \\
7 \cdot 1 \pm 0.1 \\
6.9 \pm 0.1\end{array}$ & $\begin{array}{l}27 \cdot 5 \pm 3 \\
21 \cdot 7 \pm 3 \\
18 \cdot 7 \pm 2 \\
14 \cdot 8 \pm 4\end{array}$ & $\begin{array}{l}1274 \pm 260 \\
1252 \pm 197 \\
1185 \pm 220 \\
1128 \pm 178\end{array}$ & $\begin{array}{l}7.2 \pm 0.9 \\
7.3 \pm 0.9 \\
7.3 \pm 0.9 \\
7.8 \pm 0.7\end{array}$ \\
\hline
\end{tabular}

Number tested with leucocytes $=10$ : without leucocytes $=10$.

$\mathrm{ND}=$ no data.

difference in the response between the two types of pack ( $p>0.05$; Table 1). Although the serotonin uptake fell during the seven days storage there was no significant difference in the level of uptake obtained after seven days storage in either type of bag ( $p>0.05$; Table 1$)$.

In a study of 116 units of platelet concentrates a very low level of leucocyte contamination was found in $89 \%$ of the units (WBC per unit $<5 \times 10^{8}$ ), although some units were heavily contaminated (WBC per unit $\left.5-18 \times 10^{8}\right)$. Since comparative assessment of Fenwal and Cutter packs showed no significant difference (Table 1), paired studies were carried out irrespective of container, in order to determine whether the presence or absence of significant leucocyte contamination affected the in vitro viability of the accompanying platelets.

The preparations were heavily contaminated with leucocytes and the leucocyte count fell during the storage period whereas the platelet count remained unaltered (Table 2). During storage there was a more notable increase in platelet MPV in the presence of leucocytes (Table 2). Macroaggregates were present in the packs with buffy coat after only three days and accumulated with storage. Both the $\mathrm{pH}$ and glucose levels were very significantly affected by leucocyte contamination (Table $2, \mathrm{p}<0.001$ ).

After seven days storage in the presence of buffy coat the platelets had minimal hypotonic shock response and serotonin uptake. The $\mathrm{pH}$ was below 6.2 in eight of the 10 paired units tested and these units were unsuitable for transfusion after five days storage.

Plasma fibrinogen concentration did not alter significantly over the seven day storage interval, whether platelets were stored with buffy coat $(\mathrm{n}=10) \quad$ (day $\quad 0=2 \cdot 2 \mathrm{mg} / \mathrm{ml} \pm 0 \cdot 1 ;$ day $7=2.6 \mathrm{mg} / \mathrm{ml} \pm 0.6)$ or without buffy coat $(\mathrm{n}=10)$ (day $0=2.5 \mathrm{mg} / \mathrm{ml} \pm 0.3 ;$ day $7=2.7 \mathrm{mg} / \mathrm{ml} \pm$ $0 \cdot 3)$.

The binding of a monoclonal antibody AN51 to formaldehyde-treated platelets was studied. There was no alteration in the level of binding to platelets stored in the absence of buffy coat, $(n=6$ ) (day $7=100 \%$ ). However, there was only marginal reduction in the level of binding when platelets were stored in the presence of buffy coat, $(n=6)$ (day $7=89 \cdot 5 \%)$. 


\section{CLINICAL STUDIES}

Thirty-six units of platelets stored in PL-732 packs were transfused on the fifth day of storage into three adult patients with acute myeloblastic leukaemia. A further 36 units of platelets stored in CLX packs were transfused into three further adult patients with acute myeloblastic leukaemia. All patients were thrombocytopenic and received six units of platelets on two successive days. One patient in each group had, at the time of the platelet transfusion, evidence of active bleeding into the skin and gums, and both had platelet counts of $<10 \times 10^{9} / 1$. Six units of platelets stopped the bleeding in both patients within four hours but in neither case could an increment in platelet count be demonstrated. After the second platelet transfusion the following day the peripheral blood platelet count had risen, six hours after the infusion, to $22 \times 10^{9} / 1$ (CLX platelets) and $31 \times 10^{9} / 1$ (PL-732 platelets) respectively.

Although the platelet counts in the other four patients ranged from $12-21 \times 10^{9} / 1$ there was no clinical evidence of active bleeding. After the infusion of a total of 12 units of platelets, increments in peripheral blood counts could be demonstrated in all four patients. The platelet count rose in the two patients who received platelets stored in CLX to 64 and $77 \times 10^{9} / 1$ respectively and in those patients who received P.L-732 platelet concentrates to 54 and $89 \times 10^{9} / 1$.

\section{Discussion}

Murphy et al ${ }^{15}$ have shown that platelet packs constructed of PL-732 have increased permeability to oxygen compared to PL-146 with the resultant better maintenance of $\mathrm{pH}$ during storage of platelet concentrates. Oxygen has been shown to pass into packs constructed of CLX more rapidly than into packs of di-(2-ethyl-hexyl)phthalate formulation. ${ }^{16}$ The findings presented here confirm that $\mathrm{pH}$ is well maintained in both PL-732 and Cutter CLX packs.

Beutler and $\mathrm{Kuhl}^{17}$ demonstrated the potential role of contaminating white blood cells on platelet storage. Residual leucocytes were reported to show very appreciable effect on lactate production and $\mathrm{H}^{+}$ion concentration but not glucose consumption of platelet concentrates stored in PL-146 packs for three days. Storage of platelet concentrates in PL-732 or CLX packs for seven days in the presence of buffy coat resulted in a very significant fall in $\mathrm{pH}$ and an increase of glucose consumption. Contamination of the platelet packs with low levels of erythrocytes or low levels of leucocytes appeared to have no effect on the glucose consumption, lactate production or fall in $\mathrm{pH} .{ }^{1718}$ Although different plastics with superior gas exchange to that of PL-146 were used in this study, heavy leucocyte contamination resulted in increased glucose consumption and a substantial fall in $\mathrm{pH}$ even after three days storage. Clearly this fall in $\mathrm{pH}$ affected the in vitro viability of the platelets.

Plasma fibrinogen was not activated in the presence or absence of buffy coat suggesting the appearance of macroaggregates in packs with buffy coat and the corresponding fall in white cell count was due to aggregated white cell debris. Further investigations may indicate whether other plasma proteins may be affected.

AN51 binding studies using platelet concentrates stored for up to seven days in the absence of buffy coat suggest there was no detectable loss of GPIb during storage of these platelets. Similar findings were found for platelet concentrates stored for up to $72 \mathrm{~h}$ at $22^{\circ} \mathrm{C}$ in PL-146 packs. ${ }^{19}$ However, storage in the presence of buffy coat may cause some reduction in the level of GPIb possibly as a result of proteolysis. $^{20}$ Although the activity of the platelet calcium-dependent protease may be inhibited by the presence of citrate, leucocytes are a very rich source of proteolytic enzymes. Proteolytic enzymes may be released from damaged leucocytes and cleave membrane glycoproteins and the presence of a chymotrypsin-like enzyme from human leucocytes has been demonstrated. ${ }^{21}$

The small clinical study indicated that platelet concentrates stored in CLX or PL-732 for five days were effective in stopping active bleeding in two thrombocytopenic patients and that satisfactory increments in peripheral blood platelet counts could be demonstrated in six patients after the infusion of 12 units of platelets.

The in vitro studies have shown that approximately one in ten platelet preparations could be contaminated with leucocytes and therefore significantly reduce platelet viability. It is usual to transfuse adult patients with six units of platelets per day and there would therefore be a risk that every two or three days one unit may contain platelets of poor viability. However in paediatric practice young children may require less units of platelets each day and it would be most important to identify units where the viability of the platelets is suspect.

In conclusion, the $\mathrm{pH}$ and in vitro platelet viability were maintained with storage for up to seven days using either PL-732 or Cutter CLX packs. The work suggests it is essential to ensure very low levels of contaminating leucocytes are achieved as these can adversely affect the $\mathrm{pH}$ and glucose concentration and hence the viability of the platelets during in vitro storage.:As irreversible aggregation of leucocytes 
may occur during the platelet concentrate centrifugation the measurement of $\mathrm{pH}$ and/or glucose from a stripline sample of the unit after three days storage in vitro are suggested as a routine measure of suitability for transfusion.

Our grateful thanks are due to Travenol Laboratories Limited and Cutter Laboratories Limited for providing the blood packs used in this study and to Dr AJ McMichael for his kind donation of AN51. The expert technical assistance of $\mathrm{Mr} \mathbf{M}$ Barry and Mrs $\mathbf{M}$ Prosser are gratefully acknowledged. We thank Miss H Lane and Mrs G Simmonds for preparing the manuscript.

\section{References}

' International Forum. Which are the parameters to be controlled in platelet concentrates in order that they may be offered to the medical profession as a standard product with specific properties? Vox Sang 1981;40:115-26.

${ }^{2}$ Murphy S, Sayar SN, Gardner FH. Storage of platelet concentrates at $22^{\circ} \mathrm{C}$. Blood $1970 ; 35: 549-77$.

${ }^{3}$ Slichter SJ, Harker LA. Preparation and storage of platelet concentrates II. Storage variables influencing platelet viability and function. Br J Haematol 1976;34:403-19.

${ }^{4} \mathrm{Kim}$ BK, Baldini MG. The platelet response to hypotonic shock. Its value as an indicator of platelet viability after storage. Transfusion 1974;14:130-8.

5 Tandy NP, Taylor MA. Platelet concentrates for transfusion control of production and storage. Med Lab Sci 1980;37:127-36.

${ }^{6}$ Taylor MA. Cryopreservation of platelets: an in vitro comparison of four methods. J Clin Pathol 1981;34:71-5.

${ }^{7}$ Schiffer CA. Abstract on quality control monitoring of platelet transfusions. 7th Annual Symposium on Blood Transfusion, Gröningen, the Netherlands, 1982.

${ }^{8}$ Berseus O, Hogman CF, Johansson A. Simple method of improving the quality of platelet concentrates and the importance of production control. Transfusion 1978;18:333-8.
${ }^{9}$ Odeberg H, Olsson I, Venge P. Cationic proteins of human granulocytes. Lab Invest 1975;32:86-90.

${ }^{10}$ Mourad N. A simple method of obtaining platelet concentrates free of aggregates. Transfusion 1968;8:48.

"Ingrams I. Method for clottable fibrinogen assay. $J$ Biochem 1982;51:583.

${ }^{12}$ Macfarlane DE, Stibbs J, Kirby EP, Zucker MB, Grant RA, Macpherson J. Method for assaying von Willbrand Factor. Thrombosis et Diathesis Haemorrhagica 1975;34:306-8.

${ }^{13}$ McMichael AJ, Rust NA, Pilch JR, et al. Monoclonal antibody to human platelet glycoprotein I. i. Immunological studies. $\mathbf{B r} \mathbf{J}$ Haematol 1981;49:501-9.

${ }^{14}$ Jensenius JC, Williams AF. Binding of anti-immunoglobulin antibodies to rat thymocytes and thoracic duct lymphocytes. Eur J Immunol 1974;4:91-7.

${ }^{15}$ Murphy S, Kahn RA, Holme S, et al. Improved storage of platelets for transfusion in a new container. Blood 1982;60:194-200.

${ }^{16}$ Archer GT, Grimsley PG, Jindra J, Robson JE, Ribeiro A. Survival of transfused platelets collected into new formulation plastic packs. Vox Sang 1982;43:223-30.

${ }^{17}$ Beutler E, Kuhl W. Platelet glycolysis in platelet storage IV. Effect of supplemental glucose and adenine. Transfusion 1980;20:97-100.

${ }^{18}$ Moroff G, Friedman A, Robkin-Kline H. Factors influencing changes in $\mathrm{pH}$ during storage of platelet concentrates at 20 $24^{\circ}$ C. Vox Sang 1982;42:33-45.

19 Taylor MA. The functional viability of human platelets during in vitro storage. University of Bristol: PhD thesis, 1982.

${ }^{20}$ Phillips DR, Jakabova M. Calcium-dependent protease in human platelets: specific cleavage of platelet polypeptides in the presence of $\mathrm{Ca}^{2+}$.J Biol Chem 1977;252:5602-5.

${ }^{21}$ Hogman CF, Hedland K, Akerblom O, Venge P. Red blood cell preservation in protein-poor media. 1. Leucocyte enzymes as cause of haemolysis. Transfusion 1978;18:233-41.

Requests for reprints to: Dr ID Fraser, South Western Regional Blood Transfusion Centre, Southmead Road, Bristol BS10 5ND. England. 